\title{
Phytoprotection
}

\section{Plaque commémorative du centenaire de la SPPQ}

\section{Léon-M. Tartier}

Volume 89, numéro 2-3, décembre 2008

Journée commémorative du centenaire de la société de protection des plantes du Québec

Centennial Commemoration of the Québec Society for the Protection of Plants

URI : https://id.erudit.org/iderudit/038248ar

DOI : https://doi.org/10.7202/038248ar

Aller au sommaire du numéro

\section{Éditeur(s)}

Société de protection des plantes du Québec (SPPQ)

\section{ISSN}

0031-9511 (imprimé)

1710-1603 (numérique)

Découvrir la revue

Citer ce document

Tartier, L.-M. (2008). Plaque commémorative du centenaire de la SPPQ.

Phytoprotection, 89(2-3), 165-165. https://doi.org/10.7202/038248ar d'utilisation que vous pouvez consulter en ligne.

https://apropos.erudit.org/fr/usagers/politique-dutilisation/ 


\title{
Plaque commémorative du centenaire de la SPPQ
}

\author{
Léon-M. Tartier
}

PHYTOPROTECTION 89: 165

Je tiens d'abord à remercier tous les membres du comité du centenaire qui ont contribué d'une façon ou d'une autre à la préparation de cette plaque commémorative. De vifs remerciements sont adressés au Dr Luc Couture qui a su mener à terme ce magnifique projet de plaque commémorative.

La plaque est gravée en français et en anglais pour bien refléter que, dès ses débuts, notre Société se voulait bilingue, ce à quoi elle n'a pas dérogé depuis ce temps.

La description spécifie que la SPPO est la plus ancienne société scientifique de phytoprotection au monde étant toujours active sous son nom original. II est vrai que dès sa création, la Société s'est toujours intéressée à tous les ennemis des plantes; nous sommes d'ailleurs des pionniers dans la lutte biologique ou "intégrée", qui ne portait pas encore ce nom en 1908.

Notre Société, fondée le 24 juin 1908, a 100 ans et elle est toujours bien vivante. C'est avec une grande fierté que nous fêtons son centième anniversaire. Cette plaque commémorative va perpétuer le souvenir et le dynamisme de notre Société pour ceux qui vont nous succéder, car elle semble bien partie pour un autre 100 ans!

Longue vie à la Société de protection des plantes du Québec! Long live the Québec Society for the Protection of Plants!

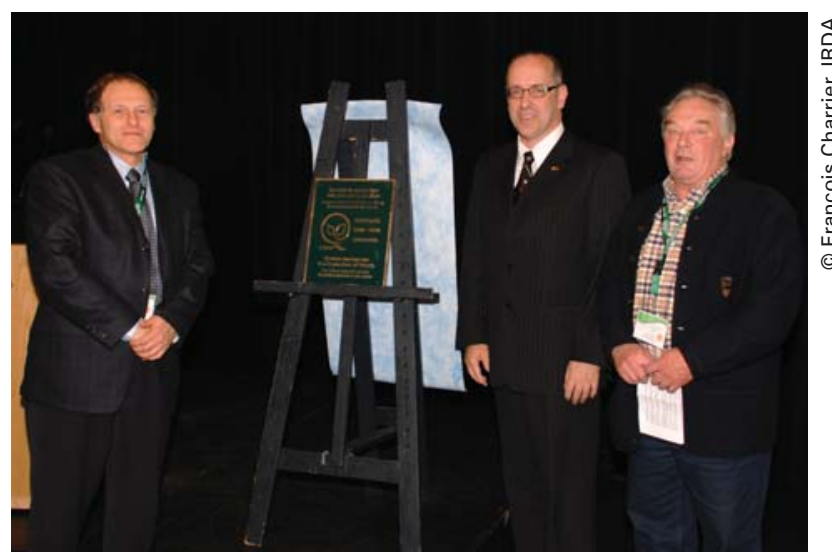

Luc Couture, lauréat de I'Hommage Pierre-O.-Thibodeau, Jean-Paul Laforest, doyen de la Faculté des sciences de I'agriculture et de l'alimentation (FSAA) de I'Université Laval, et Léon-M. Tartier. La plaque commémorative a depuis été installée dans le hall du Pavillon Paul-Comtois (FSAA) de l'Université Laval.

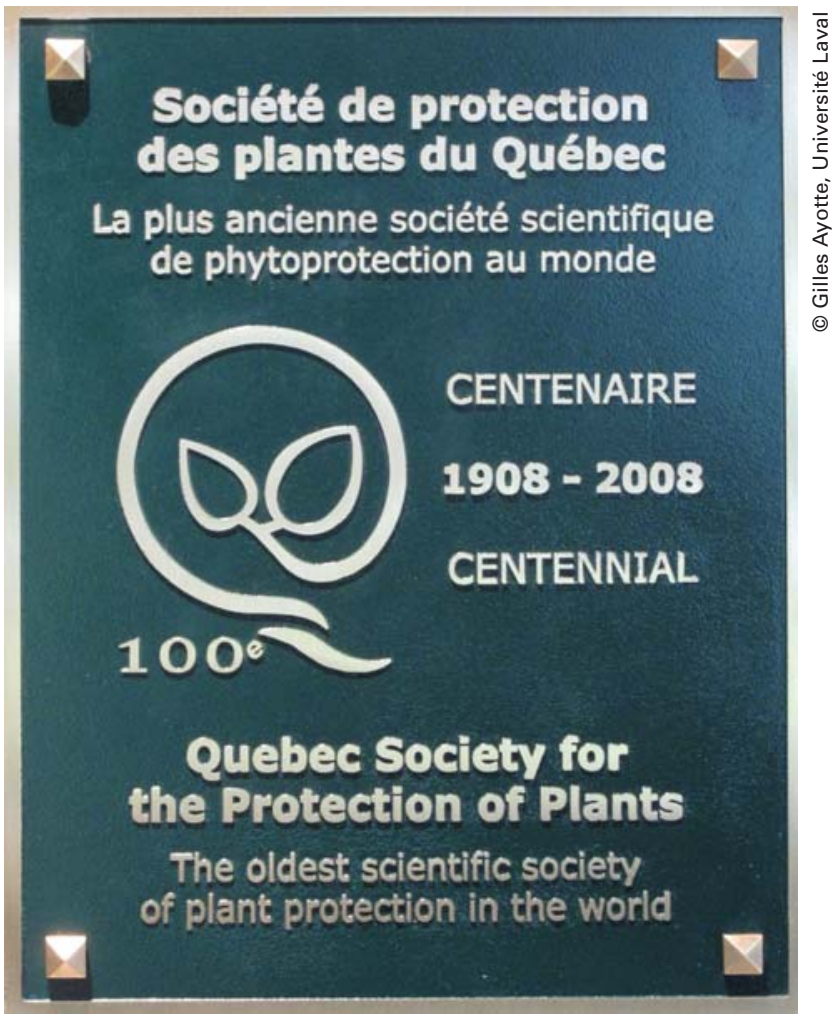

Plaque commémorative dévoilée par M. Léon-M. Tartier, membre honoraire de la Société, secrétaire de la SPPQ pendant plus de 30 ans et lauréat du prix Hommage Douglas-Weir/Marc-André Richard. 